\title{
Global politics, postcolonialism and cultural studies
}

\author{
Política global, pós-colonialismo e estudos culturais
}

\section{Fabiano P. Mielniczuk}

\begin{abstract}
This paper is an attempt to pave the theoretical way to substitute the political for politics. After illustrating how mainstream IR theories reify the State as the dominant form of subjectivity, I explore the power ontology shared by the critics of this mode of representation. In my view, this conception of power explains why critical theorists have a broader and richer perspective that serves their aim of rethinking the political. This new ontology is presented through a reading of Foucault's analytics of power: the juridico-discursive representation of power, which is attributed to mainstream scholars, is opposed to the power-as-productive representation, which I believe critical theorists share. By reading Darby's The Fiction of Imperialism and Said's Orientalism through the foucauldian categories of strategy and tactics, I attempt to illustrate how the power-as-productive figuration can be deployed to destabilize the juridico-discursive one. This is one way of locating where cultural studies and postcolonialism meet global politics.
\end{abstract}

\section{Keywords}

Global Politics; Postcolonialism; Cultural Studies; Foucault's Analytics of Power.

\section{Resumo}

Este artigo é uma tentativa de pavimentar o caminho teórico para substituir a política pelo político. Depois de ilustrar como as principais teorias de RI reificam o Estado como a forma dominante de subjetividade, eu exploro a ontologia de poder compartilhada pelos críticos desse modo de representaçáo por meio de uma leitura da "analítica do poder" de Foucault: a representação jurídico-discursiva do poder, que é atribuída aos estudiosos convencionais, se opõe à representação do poder como produtivo, que acredito que os teóricos críticos compartilham. Ao ler A ficçáo do Imperialismo de Darby e Orientalismo de Said por intermédio das categorias foucaultianas de estratégia e tática, tento ilustrar como a configuração do poder como produtivo pode ser empregada para desestabilizar a figuração jurídico-discursiva. Esta é uma maneira de localizar onde os estudos culturais e o pós-colonialismo encontram a política global.

\section{Palavras-chave}

Política Global; Pós-colonialismo; Estudos Culturais; Analítica do Poder de Foucault. 


\section{Introduction 1}

One might judge the intricacy of global politics, postcolonialism and cultural studies through the examination of the disciplinary consequences of George Floyd's murder, on May 2020. As it ignited huge global demonstrations against racism, Foreign Policy Magazine (FPM) invited non-mainstream scholars to write about racism in the International Relations discipline (IR). Bhambra et al. (2020) accepted the challenge and, as the title of their collective piece suggests, claimed that mainstream IR is blind to racism. The pervading argument knitting the individual contributions together is that Westerncentrism makes the discipline unreflective about the fundamental role that race and racism play. Being blind demands an effort to efface the colonial and imperial uses of IR from its origin, which results in the denial of nonwestern subjectivities until the present. There is also the concealment of race and racism from its disciplinary history through inaccurate mythologizing narratives. These are the motives that make race and racism disappear from the research agendas of the current practitioners. IR discipline confirms the assertion by Charles Mills: "White Supremacy," he writes, "is the unnamed political system that has made the modern world what it is today. You will not find this term in introductory, or even advanced, texts in political theory" (MILLS, 1997, p. 9). ${ }^{2}$

In theoretical terms, one alternative to the neglect of race and racism in IR might be the conversion to postcolonial studies. Postcolonial theory is centrally committed to the denouncing of the racist underpinnings of Western knowledge and its downplaying effects on colonial subjects (GANDHI, 1998; CHAKRABARTY, 2007; LOOMBA, 2015). In fact, the works of Fanon (2008), Said (2003), Bhabha (2004) and Spivak (1988) influence a major part of scholars that are sensitive to the long absence of race and racism in mainstream IR (KRISHNA, 2008; SAJED, 2013; SHILLIAM, 2009; PERSAUD, 1997; CHOWDHRY, 2007; BISWAS, 2007; NAIR, 2007; DARBY and PAOLINI, 1994). Two problems make this alternative unfeasible though. First, the different perspectives brought by postcolonial thinkers make its

\footnotetext{
${ }^{1}$ The writing of this paper begun when I was a research fellow at Hawaii University during my Ph.D Program at IRI/PUC-Rio. This experience was possible due to the financial support of CAPES and the academic support of João Pontes Nogueira and Michael J. Shapiro. I am also grateful to my colleagues at the Graduate Program of Political Science at UFRGS where I research and teach topics related to this paper.

${ }^{2}$ I owe this quote to Mike Shapiro. In fact, as the reader will notice, I owe way more than that to Mike's generosity in our undergoing conversations during the last years.
} 
adoption an uncomfortable fit in disciplinary lines. Psychoanalysis, Marxism, Feminism, Literary Criticism and Poststructuralism are all intertwined in postcolonial analysis and might have a destabilizing effect in the defining contours of IR (on these issues, see SINHA and VARMA, 2017; GREEDHARRY, 2008; LAZARUS, 2004; LEWIS and MILLS, 2003). The second and most challenging problem relates to the colonial/imperial origins of the discipline. As many authors in the FPM articles underscore, Political Science/IR institutionalization served colonial purposes of imperial domination and its subsequent developments brought with it its birthmarks (see also SHAPIRO, 2004; VITALIS, 2017; BLATT, 2018). In that sense, Krishna (2001) rightly points out that Postcolonial IR is an oxymoron. ${ }^{3}$

Acknowledging the incompatible nature between IR and postcolonialism serves as a caveat that the former offers more than a valuable contribution to broaden the disciplinary boundaries of the latter. In fact, postcolonialism has the potential to implode them. Such a drastic move starts by abandoning two pervasive forms of governance that limit our understanding of politics. The disciplinary boundaries of mainstream IR are strictly contained by the prevalence of objectivism as the sole criteria of legitimacy to political knowledge, a situation that might be described as the epistemic governance that rules the field. In its turn, the effects of this discourse are reinforced by another kind of governance, the colonial, that presupposes political reality "the way it is" and reproduces its inequalities through the effacement of the violent practices that brought us to the present, foreclosing what might have been.

This contribution is my first step in the way that leads to IR's implosion, emancipating political analysis from both the epistemic and colonial governance mentioned above. In order to do so it is necessary to abandon politics and "bring the Political back in" - to borrow the subtitle of a provocative and groundbreaking book written by Edkins (1999) on poststructuralism and IR 4 . According to her, politics consists of activities that involve phenomena that "naturally" belong to the political.

\footnotetext{
${ }^{3}$ It is curious how the incompatibility between postcolonialism and IR is unconsciously demonstrated by Ashis Nandy, another exponent of postcolonial thinking. In conversation with Alejandro (2018), he was surprised to know that one paper of his authorship was published in the International Studies Review (NANDY, 2002). He had no idea about the existence of the journal and concluded that the editors might have published a written version of the speech he delivered in one ISA section to honor him. His bewilderment was due to the fact that he had never written "a word" on International Relations. Boris Zabolotsky brought this example to class during the Postcolonial Political Theory course at UFRGS, in 2020. The readers can reach their own conclusions reading Nandy (2009).

${ }^{4}$ Shapiro (1989) offered the same argument.
} 
On the other hand, the political refers to the conditions necessary for these events to be part of politics. In general, the constitution of the political is the process through which subjectivities are entitled or not to take part in the world of politics. Hence, the analysis of the political is the analysis of the constitution of the subject, while politics is the denial of the contingent character of this process. In focusing on wars, diplomacy, international treaties and the like as manifestations of politics, IR scholars neglect the conditions for the emergence of the modern political subject par excellence - the sovereign state - accepting it as a given and naturalizing the consequences of its violent performances against unadjusted subjects, both inside and outside. In this sense, politics is a technology of power that works towards the depoliticization of the political (EDKINS, 1999).

The rest of the paper is an attempt to pave the theoretical way to substitute the political for politics. After illustrating how mainstream IR theories reify the State as the dominant form of subjectivity, I explore the power ontology shared by the critics of this mode of representation. In my view, this conception of power explains why critical theorists have a broader and richer perspective that serves their aim of rethinking the political. This ontology is presented through a reading of Foucault's analytics of power: the juridico-discursive representation of power, which is attributed to mainstream scholars, is opposed to the power-as-productive representation, which critical theorists share. By reading Darby's The Fiction of Imperialism and Said's Orientalism through the foucauldian categories of strategy and tactics, I attempt to illustrate how the power-as-productive figuration can be deployed to destabilize the juridico-discursive one. This is one way of locating where cultural studies and postcolonialism meet global politics.

\section{Problematizing the modern subject}

The concept of the State is considered central in international relations theory and practice. Following Weber's traditional definition, mainstream scholars in the field take for granted that the State represents the monopoly of the legitimate use of force in a certain territory. This rendering conceives States as ontological beings detached from each other, which assures that they can autonomously determine the future of its constituent individuals inside, and do whatever they wish in relation to its outside. On the one hand, it contributes to reinforce the conjunction between the State, the nation, the territory and sovereignty. On the other, it gives birth to the imaginary of units interacting in an anarchic international realm. The predominance of rationalist 
thinking during the 1970's and 1980's has contributed to consolidate that image, taking the State for granted and conferring to both the State and the international system an ahistorical character, as a corollary of the rationality attributed to the Stateas-actor figuration. This inside/outside dichotomy limits the analyst's capacity to imagine different ways of organizing political life. As a consequence, the State's traditional definition perpetuates itself in the discursive economy of international relations.

Dissident scholars have noticed that fact and have launched vigorous attacks on this predominant conception of subjectivity. Cox (1986) criticizes traditional scholars' ahistorical use of the concept of the State, and argues that, if one wants to understand how the concept has changed its meaning through time and space, then historical materialism should be brought to the analysis. He contends that the concept of the State represents a specific configuration of the relations among elements that constitute historical structures (ideas, material capabilities and institutions) and that the State may even be substituted by different forms of political organization. Ashley (1989) holds that the definition of subjectivity is an effect of a modern discourse's structural logocentrism. A logocentric structure is one in which a first term is defined through relation to its opposite and both are hierarchically arranged such that the former is portrayed as superior to the latter. Such a strategy is deployed to hide the lack of foundation for delimiting subjectivities. This is so because the disjunction between subject and the social practices that demarcate it stabilizes their meaning and helps to fix its sovereign presence. Consequently, the denial of its historicity produces a center of authority that serves as a foundation for its own identity. Ashley points out that this strategy was deployed during the transition to modernity: a universal and absolute Reason was sustained in opposition to its historicity through the introduction of narratives that disqualified what was not "Rational," and this opposition was then used to naturalize Reason as epistemology's only secure foundation. The outcome of this process is what Ashley (1989) terms the paradigm of sovereign man.

Campbell (1996a) sees the same movement applied to collective aggregates informed by the sovereignty problematic: a meta-narrative of subjectivity, which confers to the subject the capacity to shift its interaction to objects, other subjects and its own body, a process which, in a reified phenomenon, is indeterminate and fluid. Those who deploy this logic in international relations emphasize sovereignty as the defining attribute of the subject, and the way that they assure its legitimacy follows the very well-known practice of disqualifying its opposite, anarchy; hence, a recurrence of dichotomies associated with both terms (order/disorder, security/insecurity, 
liberty/violence, etc.) ensues as a way to fix its meaning (ASHLEY, 1988, 1989; CAMPBELL, 1998; WALKER, 1993). Imbued with critical purpose, many authors have criticized the implications of such practices. Walker (1997) warns that the sovereign state is reproduced by practices of exclusion of other identities (class, race, gender, humanity) and questions the extent to which such practices debilitate our ability to think of alternatives to security problems. Doty (1997) stresses that the agentstructure debate is limited because of how the sovereignty problematic informs it - the reification of agency which is needed to oppose it to structure diminishes the importance of social practices, and hinders alternatives that might help scholars escape this false dichotomy. Campbell (1996b) cautions that, when the definition of subjectivity is taken for granted, both problems of identity and violent efforts to solve them are neglected.

Although these critiques have intrinsic value just by showing the consequences of accepting the State as the main subject of international relations, I argue that their most important contribution is bringing to the fore a conception of power as "productive," in opposition to the mainstream treatment of power as "juridicodiscursive." That is why, for instance, they do not get stuck in the inside/outside dichotomy that mainstream scholars pose, and can denounce the ethical implications of its adoption "both ways". In the next section, I turn to Foucault's analytics of power to explain the differences between these two representations of power and present alternative ways of treating subjectivities that conjoin postcolonialism and cultural studies.

\section{Foucault's analytics of power}

According to Foucault (1990), a certain representation of power is deeply rooted in the history of the West which limits the analysis of power. Foucault formulates this account while opposing two renderings of the relation between sexual desire and power. The first supposed that power represses desire. In this case, the only alternative to power would be its negation, and the consequent liberation of sexual drives. The second supposes that power and desire are mutually constitutive; thus, the existence of desire is, per se, the affirmation of power. Foucault recognizes that although the renderings differ in the way they conceive the dynamics between sexual drives and power, they both operate by basing their representations of power on negations: there is a rule that regulates sexual practices, that prohibits certain practices, that censors what can be said or done, and that endlessly reproduces these mechanisms 
by trespassing all levels of social life. He calls this the juridico-discursive representation of power: "It is defined in a strangely restrictive way [...], it is the power that only has the force of the negative on its side, a power to say no [...], it is a power whose model is essentially juridical, centered on nothing more than the statement of the law and the operations of taboos" (FOUCAULT, 1990, p. 85).

The historical origins of such representation are found in the monarchy and State apparatus. During the transition from the Middle Ages, these institutions of power developed as regulators of other institutions, and gained legitimacy by imposing order on them. The moment when one center of authority was imposed over the others marked the formation of a unitary regime, the identification of this center with the law, and the authorization of interdiction and sanction. Such concentration is more than a pre-condition for the emergence of law as the only way to exercise power in western societies; "[...] it is the code according to which power presents itself and prescribes that we conceive of it" (FOUCAULT, 1990, p. 88). In fact, the critiques against power were addressed at the monarchy or at the aristocracy, and not at the juridico-discursive representation that emerged with them. It is exactly this universalizing feature that makes this form of representing power conform with general statements such as, "power is tolerable only on condition that it mask a substantial part of itself," or "its success is proportional to its ability to hide its own mechanisms." The permanence of the juridico-discursive representation of power then seems obvious: "would they accept it if they did not see it as a mere limit placed on their desire, leaving a measure of freedom - however slight - intact? Power as a pure limit set on freedom is, at least in our society, the general form of its acceptability" (FOUCAULT, 1990, p. 86).

But Foucault tracks shifts in the operation of power from the eighteenth century onwards. Indeed, power radically altered how it masked itself. In contrast to the juridico-discursive representation, he can note the emergence of "[...] new methods of power whose operation is not ensured by right but by technique, not by law but by normalization, not by punishment but by control, methods that are employed on all levels and in forms that go beyond the state and its apparatus" (FOUCAULT, 1990, p. 89). This new development of methods that go "beyond" the State is the backdrop for Foucault's (1990, p. 89) famous remark that "[...] in political thought and analysis, we still have not cut off the head of the king." The statement warns that the old representation of power as juridico-discursive still persists despite all the abovementioned changes of modernity; and it is exactly this continuity that his analytics of power, "[...] the definition of the specific domain formed by relations of power, and 
towards a determination that will make possible its analysis," allows him to uncover (FOUCAULT, 1990, p. 82).

Foucault describes these power operations to disclose a new ontology that will allow the effects of power to be addressed theoretically. This new conception of power

There is no power, but states of power which are fluid because they originate from a multiplicity of force relations that are spread everywhere. Hence, power is omnipresent not because it controls space, but because it emerges from all over it. Moreover, power is not acquired; it is exercised in manifold relations of force coming from below, not concentrated in one center. In turn, this implies that power and resistance are inseparable. Foucault's (1990, p. 93) famous remark that "politics is war pursued by other means" should be understood within this context.

These transformations are associated with the emergence of bio-power; the entry of life into history. As Foucault (1990, p. 142) explains, due to "[...] the development of different fields of knowledge concerned with life in general, the improvement of agricultural techniques, and the observations and measures relative to man's life and survival" a "relative control over life averted some of the imminent risks of death." The major difference between the juridico-discursive and bio-power representations is that the latter takes the form of an affirmation of life, while the former is based on its denial, with the ever-present threat of death as a result of the Sovereign's will. Bio-power, then, is "[...] what brought life and its mechanisms into the realm of explicit calculations and made knowledge-power an agent of transformation of human life" (FOUCAULT, 1990, p. 143). However, instead of relaxing the control power exerts, the affirmation of life tightens its grip over man by creating a normalizing society.

This normalizing effect is the consequence of relative control over life achieved through knowledge about man. In fact, the power-knowledge nexus is made explicit when one considers that the condition of emergence of bio-power is the new relation between history and life, "[...] in this dual condition of life that placed it (man) at the same time outside history, in its biological environment, and inside human historicity, penetrated by the latter's techniques of knowledge and power" (FOUCAULT, 1990, 
p. 143). Power assumes, in this rendering, a productive capacity that is alien to the juridico-discursive representation, exactly because bio-power's ontology considers power to be ubiquitous, both spatially and discursively, and not concentrated in one central point. The following passage summarizes this view of power as productive:

Relations of power are not in a position of exteriority with respect to other types of relationships (economic processes, knowledge relationships, sexual relations), but are immanent in the latter; they are the immediate effects of the divisions, inequalities and disequilibriums which occur in the latter, and conversely they are the internal conditions of these differentiations; relations of power are not in superstructural positions, with merely a role of prohibition or accompaniment; they have a direct productive role, wherever they come into play. (FOUCAULT, 1990, p. 94).

This productive role has a consequence for the study of the subject: bio-power produces subjectivities through social practices that are embedded in processes of power-knowledge. Knowledge of man subjects man to a discourse that is aimed at protecting life, but also regulates what life is supposed to be - this is man's condition as subject. The same holds true for collective aggregates: "[...] the analysis, made in terms of power, must not assume that the sovereignty of the State, the form of the law, or the overall unity of a domination are given at the outset; rather, these are only the terminal forms power takes" (FOUCAULT, 1990, p. 92). The inclusion of Foucault's cautionary prescription ("rule of immanence") that "[...] between techniques of knowledge and strategies of power, there is no exteriority" (FOUCAULT, 1990, p. 98) leads to the conclusion that any study of subjectivity that does not consider the constitutive role performed by power-knowledge is doomed to fail.

This Foucauldian perspective on power has important implications. The first is that studies that take this ontology seriously will yield questions about subjectivity when they focus on power-knowledge, and vice-versa. It is impossible to treat them as independent spheres, attached to different objects of inquiry. The reason has already been stated: understanding the qualities of one will presuppose acknowledgement of the other; it is a process that works both ways. The second important consequence is that both power-knowledge relations and subjectivities belong to the discursive realm. Of course, there might be "local centers," in opposition to a "central point," where power-knowledge materializes. Foucault mentions, for instance, the body of the child, "[...] under surveillance, surrounded in his cradle, his bed, or his room by an entire watch-crew of parents, nurses servants, educators, and the doctors, all attentive to the 
least manifestations of his sex" (FOUCAULT, 1990, p. 98). But these local centers symbolize one power-knowledge discourse that engenders in itself a discourse of subjectivities: the child gains its subjectivity by being subjected to a discourse on sexuality that demarcates what is normal and what is pathological. The third consequence is that these two features, the connectedness of power-knowledge with subjectivity and their discursive nature, are valid both to individual and collective subjects. For instance, the discourse on sex puts the individual subject (the child) in a subjected position in relation to the collective subject, i.e. the State, from which regulations about right and wrong emanate. Consequently, the juridico-discursive representation of power produces both individual and collective subjects.

This third point deserves to be further qualified by the distinction between "tactics" and "strategy." According to Foucault (1990, p. 95), "[...] the rationality of power is characterized by tactics that are often quite explicit at the restricted level where they are inscribed" and end up "forming comprehensive systems." But these systems find "their base of support and their condition elsewhere," in strategy, which coordinates tactics in an unspoken manner: "[...] the logic is perfectly clear, the aims decipherable, and yet it is often the case that no one is there to have invented them, and few who can be said to have formulated them." Foucault warns that one must resist the invitation to treat the relationship between these two dimensions as an opposition between the microscopic and the macroscopic levels, which could result in an erroneous reproduction of levels of analysis that are derived from the juridicodiscursive representation of power, and thus to an arbitrary spatial-splitting of individuals and collective subjectivities. Indeed, separating these two dimensions in spatial categories would suggest that micro-politics is based on power as productive, while macro-politics is attached to power as juridico-discursive though, in fact, power is productive everywhere. That is why "[...] one must conceive the double conditioning of a strategy by the specificity of possible tactics, and of tactics by the strategic envelope that makes them work" (FOUCAULT, 1990, p. 100).

In fact, when these findings are applied to the study of subjectivities derived from the juridico-discursive figuration, they are acts of confrontation that aim to correct the disjunction that Foucault's analytics of power unveils. Roughly, the work of critical theorists can be divided into two categories according to their reliance on "tactical" or "strategic" dimensions of analysis. One category privileges the analysis of individual subjectivities as a way to criticize collective subjects. The focus is on social practices that belong to the dimension of "tactics." The other emphasizes the 
contingent nature of power-knowledge discourses that underpin collective subjectivities. Because their emphasis relies more on power-knowledge discourses than on the "local centers" where they materialize, the analysis belongs to the "strategic" dimension. They aim to destabilize the juridico-discursive representation of power by stressing the arbitrary nature of these power-knowledge discourses.

\section{At the tactical level: Darby's "The Fiction of Imperialism"}

The work of Philip Darby exemplifies the emphasis on the tactical level. Darby (1998) attempts to reveal the productive dimension of power through analysis of fictional literature. He argues that this genre provides a privileged glimpse of constructions of narratives, and because narratives are used both in fiction and reality, studying fiction can bring the same benefits of studying reality. Because reality is understood in a multifaceted way, there is a need to organize its infinitude through a narrative that has the subject as a point of departure. If he is correct, then the narratives built about the "lives" of protagonists of literary fiction and the narratives built by scholars inside a specific disciplinary field about a scientific object are at the same time arbitrary, real and fictional.

Darby's (1998) makes his productive conception of power explicit when he contends that literary narratives could be even more real than those that scholars employ. In fact, he argues, the analysis informed by fiction is more realist than the realist fiction that dominates international relations theory, for the central concepts of this traditional approach (power politics and economic issues) arise from individual social practices, and not vice-versa. Moreover, collective aggregates contribute to the depoliticization of political analysis, because they are merely labels imposed on diversity to simplify very complex realities and solve tensions among different perspectives merely for the sake of parsimony. Darby (1998) argues that politicization of international relations requires one to personalize its subject; which is a further step that literature can achieve, because fictional literature privileges the construction of narratives from the experiences of individual subjects, not collective aggregates.

What Darby terms politicization can be easily identified with the "cutting off of the King's head" that Foucault defends. This measure is needed to demonstrate the inadequate sovereign figure portrayed by the juridico-discursive representation of power, and to reveal the risks that it engenders. Freedom from this representation, for instance, ceases the reproduction of the public/private divide, which works as a foundation of aggregate agents such as the State. Consequently, critical scholars become free to address gender issues. Questions about how race issues affect people's 
life may be explored in novels dealing with interracial relationships. Problems of cultural difference can be tackled as well, since it is through individual interactions that appraisals of these problems are changed or maintained. In summary, politicization implies that subjectivity does not derive from a Sovereign center of authority marked by well-defined boundaries demarcated through difference-subduing academic or political practices (in Foucauldian terms, the power-knowledge nexus that sustains the juridico-discursive representation and its associate subjectivity). The boundaries of power are fluid, loose and overlapping (DARBY, 1998).

Darby's (1998) analysis benefits from the encounter of literature and postcolonial studies. Postcolonialism is an approach concerned with the effects of difference on postcolonial realities. It is based on condemnation of the ways that Europeans involved non-Europeans in processes of acculturation. However, this process is not viewed from the perspective of collective aggregates, for from that perspective, there is only one legitimate aggregate, the European state, which interacts with a myriad of others which have their values as aggregates denied. Additionally, at the aggregate level, it is impossible to contest practices of colonial dominance, because the predominant discourse is one rooted in the success of the colonial enterprise: colonizers dominate the colonized, and constitute legitimate aggregates by imposing their political organizations; consequently, these aggregates are, well suited to their "civilizing project". Literature offers an escape route from this trap. Because of its personalized nature, the narrative of a novel is constructed according to an inside-out logic, which locates agency at the individual level and constructs narratives according to what is experienced there. This inside-out logic allows the analyst to find fissures in the collective aggregate discourse by distinguishing between what happens at its level, and what happens at the individual one (DARBY, 1998).

The sexuality question provides a good case for comparison. At the aggregate level, the imperialist discourse was based on a hierarchy of masculinity over femininity. Africa, for instance, was compared to a virgin continent that Europeans were meant to penetrate. In India, the Hindi population was considered effeminate because they did not resist British colonialism. At first sight, many imperialist fictions portrayed the same colonial subject. However, through careful reading of literary texts, one can see that the successful colonial enterprise was a discourse based on the public sphere. In the private sphere, the colonial project was traversed by ambiguity and insecurity. Consider two examples that undermine the dominant imperialist discourse and its associated subjectivities: 1) A white female's sexual attraction to a black slave intensifies 
violent practices of domination for she cannot possibly satisfy her desires, and 2) cases of anxious homosexual relations between colonial soldiers and natives. Both, in a Foucauldian sense, exemplify how power and resistance are interconnected. The power of such individual narratives is denied though, because they expose the absurdity of the dividing principle that authorizes Europeans to subsume difference. Those particular narratives approximate the difference, and by reading the difference, it is possible to realize that non-Europeans are as human as the Europeans (DARBY, 1998).

\section{At the Strategic Level: Said's Orientalism}

Edward Said gives a good example on how to focus on the strategic, powerknowledge discursive dimension. Said (2003) is concerned with a kind of Western imaginative geography that represents the Arabic-Muslim world in a way that he suspects does not conform with "reality." The author locates the source of this disjunction in what he calls orientalist discourse: a mode of representing the East based on a Western perspective. In a way that explicitly shows his indebtedness to Foucault's elaborations of the power-knowledge-subjectivity nexus, he states that orientalist discourse has its origins in the Western will to know the East in order to dominate it. "Orientalism can thus be regarded as a manner of regularized (or Orientalized) writing, vision, and study, dominated by imperatives, perspectives, and ideological biases ostensibly suited to the Orient. The Orient is taught, researched, administered, and pronounced upon in certain discrete ways" (SAID, 2003, p. 202). The enmeshed relation between power-knowledge and subjectivity becomes evident in this reading, because the Orient for Orientalism "[...] is a system of representations framed by a whole set of forces that brought the Orient into Western learning, Western consciousness, and later, Western empire. [...] Orientalism was itself a product of certain political forces and activities" (SAID, 2003, p. 203).

Said (2003) clearly intends to deal with power-knowledge discourses rather than with the "local centers" in which they materialize. In asking about the sources of Orientalism's intellectual authority, he states that his main methodological approaches to the issue

[...] are what can be called strategic location, which is a way of describing the author's position in a text with regard to the Oriental material he writes about, and strategic formation, which is a way of analyzing the relationship between texts and the way in which groups of texts, types of texts, even textual genres, acquire mass, density, and referential power among themselves and thereafter in the culture at large. (SAID, 2003, p. 20). 
In a very similar fashion to Foucault's understanding of strategy, he explains that the term strategy serves "[...] simply to identify the problem every writer on the Orient has faced: how to get hold of it, how to approach it, how not to be defeated or overwhelmed by its sublimity, its scope, its awful dimensions" (SAID, 2003, p. 20). Strategy and authority are intermingled when it comes to Orientalism:

\footnotetext{
Every writer on the Orient (and this is true even of Homer) assumes some Oriental precedent, some previous knowledge of the Orient, to which he refers and on which he relies. Additionally, each work on the Orient affiliates itself with other works, with audiences, with institutions, with the Orient itself. The ensemble of relationships between works, audiences, and some particular aspects of the Orient therefore constitutes an analyzable formation-for example, that of philological studies, of anthologies of extracts from Oriental literature, of travel books, of Oriental fantasieswhose presence in time, in discourse, in institutions (schools, libraries, foreign services) gives it strength and authority. (SAID, 2003, p. 20).
}

On the basis of these contributions, he develops the notion of the "orientalist stage" as "a system of moral and epistemological rigor" (SAID, 2003, p. 67). He contends that this stage is the place where intellectuals, politicians, artists, diplomats, scholars, and others perform the already-given roles between East and West. This predetermination of roles is due to the operation of the orientalist discourse in its latent and manifest forms. Said (2003, p. 206) explains the difference between these two types by noting that "[...] in the nineteenth-century writers [...] the differences in their ideas about the Orient can be characterized as exclusively manifest differences, differences in form and personal style, rarely in basic content." He then states that the basic content was "the separateness of the Orient, its eccentricity, its backwardness, its silent indifference, its feminine penetrability, its supine malleability." Hence, latent orientalism is a kind of ontological prejudice that subsumes the oriental object by keeping it always at a distance and in a position of inferiority in relation to the West, while manifest orientalism includes variations inside this purview, usually in accordance with the stage of institutionalized knowledge about the Orient. Since its inception, then, the production of knowledge has rested on power relations and has resulted in the production of a certain Oriental subject. Contemporary variations of the scientific content of manifest orientalism follow the positivist rationale of humanities and social sciences in the subfield of "orientalist studies." 


\section{Final remarks}

Darby (1998) and Said (2003) take different routes to reach the same destination. Though both want to undermine the subjectivities attached to the juridico-discursive representation of power, the former launches his attack from the tactical dimension, whereas the latter operates at the strategic one. Because these two dimensions rest on the representation of power as productive, both authors achieve the same objective. This is important, for it shows that this new ontology of power is the source of contestation of subjectivities inscribed in the juridico-discursive representation, whether they be individual or collective. Because power-knowledge discourses are spread everywhere in this new ontology, potential subjectivities are spread everywhere as well. Some authors call this the "decentralizing of the modern subject" and associate this movement with the action of "bringing the political back in" (EDKINS, 1999).

Problematizing the relation between power and knowledge is the most promising Foucauldian contribution to the present work. The rule of immanence, an expression used by Foucault to indicate the conformity between modes of interpretation and the ways power operates, asserts that modes of intelligibility are embedded in social practices. Hence, the search for objectivity gives rise to questions about the conditions that make it possible to believe that knowledge is objective in the first place. Commonly this Foucaultian way of thinking is illustrated by the suggestion that the interrogative pronoun "Why" should be replaced by "How". The subversion of the traditional mode of inquiry redirects the theoretical exercise from the relation between theory and its empirical findings to the metatheoretical level, questioning the assumptions that condition the theoretical thinking.

This discursive dimension, inhabited by what Shapiro (1989) names the "pretexts of apprehension", does not abide by disciplinary limits, thus opening up space for the appreciation of politics through other lenses. The examples above are illustrations of the crossroad where postcolonialism and cultural studies meet global politics. If the reader intends to address the questions posed in the introduction, this might be a good place to start looking for answers.

- Fabiano P. Mielniczuk é Professor na Universidade Federal do Rio Grande do Sul. E-mail: fpmiel@gmail.com 


\section{Referências}

ALEJANDRO, Audrey. Western dominance in international relations? The internationalisation of IR in Brazil and India. London, New York: Routledge, 2018.

ASHLEY, Richard K. Living on border lines: man, poststructuralism, and war. In: DER DERIAN, James; SHAPIRO, Michael (Eds.). International intertextual relations: postmodern readings on world politics. Massachusetts; Toronto: Lexington Books, 1989. p. 259-321.

ASHLEY, Richard K. Untying the sovereign state: a double reading of the anarchy problematique. Millennium-Journal of International Studies, v. 17, n. 2, p. 227, 1988.

BHABHA, Homi K. The location of culture. $2^{\text {nd }}$ ed. London; New York: Routledge. 2004.

BHAMBRA, Gurminder K. et al. Why is mainstream international relations blind to racism? Foreign Policy, July 3, 2020. Available at: <https://foreignpolicy.com/2020/07/03/why-is-mainstreaminternational-relations-ir-blind-to-racism-colonialism/>. Accessed: Nov. 15, 2021.

BISWAS, Shampa. Empire and global public intellectuals: reading Edward Said as an international relations theorist. Millennium, v. 36, n. 1, p. 117-33, 2007.

BLATT, Jessica. Race and the making of American political science. Philadelphia: University of Pennsylvania Press, 2018.

CAMPBELL, David. Writing security: United States foreign policy and the politics of identity. University of Minnesota Press, 1998.

CAMPBELL, David. Political prosaics, transversal politics, and the anarchical world. In: SHAPIRO, Michael; ALKER, Hayward R. (Eds.). Challenging boundaries: global flows, territorial identities. University of Minnesota Press: Minneapolis, 1996a.

CAMPBELL, David. Violent performances: identity, sovereignty, responsibility. In: LAPID, Yosef; KRATOCHWILL, Friedrich (Eds.). The return of culture and identity in IR theory. Boulder: Lynne Rienner Publishers, 1996b. p. 163-180.

CHAKRABARTY, Dipesh. Provincializing Europe: postcolonial thought and historical difference. Princeton, NJ: Princeton University Press, 2007.

CHOWDHRY, Geeta. Edward Said and contrapuntal reading: implications for critical interventions in international relations. Millennium, v. 36, n. 1, p. 101-116, 2007.

COX, Robert W. Social Forces, States and world orders: beyond international relations theory. In: KEOHANE, Robert (Ed.). Neorealism and its critics. New York: Columbia University Press, 1986.

DARBY, Phillip. The fiction of imperialism: reading between international relations and postcolonialism. London/Washingtion: Cassel, 1998.

DARBY, Phillip; PAOLINI, Albert. J. Bridging international relations and postcolonialism. Alternatives, v. 19, p. 371-397, 1994.

DOTY, Roxanne L. Aporia: a critical exploration of the agent-structure problematique in international relations theory. European Journal of International Relations, v. 3, n. 3, p. 365-392, 1997.

EDKINS, Jenny. Poststructuralism and international relations: bringing the political back in. Bolder (Co): Lynne Rienner, 1999.

FANON, Frantz. Black skin, white masks. Rev. ed. London: Pluto Press, 2008.

FOUCAULT, Michel. The history of sexuality: an introduction. New York: Vintage Books, 1990.

GANDHI, Leela. Postcolonial theory: a critical introduction. $2^{\text {nd }}$ ed. New York: Columbia University Press, 1998. 
GREEDHARRY, Mrinalini. Postcolonial theory and psychoanalysis: from uneasy engagements to effective critique. Hampshire; New York: Palgrave Macmillan, 2008.

KRISHNA, Sankaran. Globalization and postcolonialism: hegemony and resistance in the twenty-first century. Lanham: Rowman \& Littlefield Publishers, 2008.

KRISHNA, Sankaran. Race, amnesia, and the education of international relations. Alternatives, v. 26, n. 4, p. 401-424, 2001.

LAZARUS, Neil (Ed.). The Cambridge companion to postcolonial literary studies. Cambridge University Press, 2004.

LEWIS, Reina; MILLS, Sara (Eds.). Feminist postcolonial theory: a reader. Hoboken: Routledge, 2003. LOOMBA, Ania. Colonialism/Postcolonialism. $3^{\text {rd }}$ ed. London; New York, NY: Routledge, 2015.

MILLS, Charles W. The racial contract. Ithaca, NY: Cornell University Press, 1997.

NAIR, Sheila. FORUM: Edward W. Said and international relations. Millennium, v. 36, n. 1, p. $77-$ 82, 2007.

NANDY, Ashis. The intimate enemy: loss and recovery of self under colonialism. 2. ed. New Delhi: Oxford University Press, 2009.

NANDY, Ashis. The beautiful, expanding future of poverty: popular economics as a psychological defense. International Studies Review, v. 4, n. 2, p. 107-121, 2002.

PERSAUD, Randolph B. Frantz Fanon, race and world order. In: GILL, Stephen; MITTELMAN, James H. (Eds.). Innovation and transformation in international studies. Cambridge: Cambridge University Press, 1997. p. 170-184.

SAID, Edward W. Orientalism. New York: Penguin, 2003.

SAJED, Alina. Fanon, Camus and the global colour line: colonial difference and the rise of decolonial horizons. Cambridge Review of International Affairs, v. 26, n. 1, p. 5-26, 2013.

SHAPIRO, Michael J. Methods and nations: cultural governance and the indigenous subject. Routledge, 2004.

SHAPIRO, Michael J. Textualizing global politics. In: DER DERIAN, James; SHAPIRO, Michael J. (Eds.). International/intertextual relations. Toronto: Postmodern Readings of World Politics, 1989. p. 11-22.

SHILLIAM, Robbie. A fanonian critique of Lebow's A Cultural Theory of International Relations. Millennium, v. 38, n. 1, 2009.

SINHA, Subir; VARMA, Rashmi. Marxism and postcolonial theory: what's left of the debate? Critical Sociology, v. 43, n. 4-5, p. 545-558, 2017.

SPIVAK, Gayatri C. Can the subaltern speak? In: NELSON, Cary; GROSSBERG, Lawrence (Eds). Marxism and the interpretation of culture. Chicago: University of Illinois Press, 1988. p. 271-313.

VITALIS, Robert. White world order, black power politics: the birth of American international relations. Cornell University Press, 2017.

WALKER, Rob B. The subject of security. In: KRAUSE, Keith; WILLIAMS, Michael. Critical security studies: concepts and cases. Minneapolis: University of Minnesota Press, 1997.

WALKER, Rob B. Inside/outside: international relations as political theory. Cambridge University Press, 1993.

Texto recebido em 28 de outubro de 2021. Aprovado em 30 de novembro de 2021. 